\title{
Amphibia, Anura, Hylidae, Scinax centralis Pombal and Bastos, 1996: Distribution extension, geographic distribution map
}

\author{
Mário Ribeiro de Moura ${ }^{1 *}$, Vitor Dias Fernandes ${ }^{1}$, Diego José Santana ${ }^{2}$ and Renato Neves Feio ${ }^{1}$ \\ 1 Universidade Federal de Viçosa, Departamento de Biologia Animal, Museu de Zoologia João Moojen. Vila Gianetti 32. CEP 36570-000. Viçosa, MG, \\ Brazil. \\ 2 Universidade Federal da Paraíba, Centro de Ciências Exatas e da Natureza, Campus I, Departamento de Sistemática e Ecologia. Cidade \\ Universitária Castelo Branco. CEP 58000-000. João Pessoa, PB, Brazil \\ * Corresponding author. E-mail: mariormoura@gmail.com
}

\begin{abstract}
This work provides records of Scinax centralis from municipalities of Campo Alegre de Goiás and Orizona, state of Goiás, Brazil. Those records represent, respectively, a southeast range extension of $c a .30 \mathrm{Km}$ east and $c a$. $60 \mathrm{Km}$ southeast from the previously known locality of Ipameri. All known populations of $S$. centralis remain restricted to the Paranaíba River basin, and with exception of Orizona, all localities from where the species is known to occur are inside priority areas for conservation of biodiversity in Cerrado and Pantanal.
\end{abstract}

Scinax centralis Pombal and Bastos, 1996 is a small hylid frog belonging to the Scinax catharinae clade (sensu Faivovich et al. 2005). This species is endemic of Cerrado biome (Bastos 2007), known from three localities in central Brazil, in municipalities of Silvânia (16 $39^{\prime} \mathrm{S}$, $48^{\circ} 36^{\prime} \mathrm{W}$ ) and Ipameri (17 $\left.43^{\prime} \mathrm{S}, 48^{\circ} 09^{\prime} \mathrm{W}\right)$, state of Goiás (Pombal and Bastos 1996), and municipality of Brasília, Distrito Federal $\left(16^{\circ} 05^{\prime}\right.$ S, $47^{\circ} 50^{\prime}$ W) (Brandão and Araújo 2002).

Herein we report new records of this species for southeastern of state of Goiás. All specimens collected were housed at the herpetological collection of Museu de Zoologia João Moojen, Universidade Federal de Viçosa, municipality of Viçosa, state of Minas Gerais (MZUFV).

In October 2005, during a field expedition to the southeastern state of Goiás (GO), seven specimens of Scinax centralis were collected by RNF in municipalities of Campo Alegre de Goiás (MZUFV 6472-6473 []], MZUFV

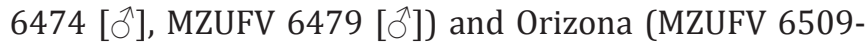
6510 [§], MZUFV 6511 []]) (Figure 1 and 2). In Campo Alegre de Goiás, specimens were collected in two localities on the right bank of the Mariquita stream $\left(17^{\circ} 41^{\prime} 53^{\prime \prime} \mathrm{S}\right.$,

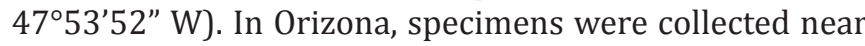
the village of Buritizinho, in isolated temporary ponds resulting from decreased flow of a stream called Córrego do Fogo (1657'36" S, 4802'57" W).

Scinax centralis is distinguished from other closely related species by its small size (SVL 17.8-21.2 mm). This species is also characterized by the presence of developed inguinal glands, snout slightly protruding in lateral view and the presence of a triangular interocular blotch (Pombal and Bastos 1996). Adult females of Scinax centralis (Figure 2) present the same characteristics of males related in the description (Pombal and Bastos, 1996). Females also have inguinal glands and the same patterns of dorsal coloration, and tend to be larger than males (Table 1). Besides the sexual dimorphism reported by Alcantara et al. (2007), two of our four males were larger in SVL than those reported in the original description (larger reported male had $21.2 \mathrm{~mm}$ ) and also those reported by Alcantara et al. (2007) (males SVL reached 17.05-23.45 $\mathrm{mm}$ ).

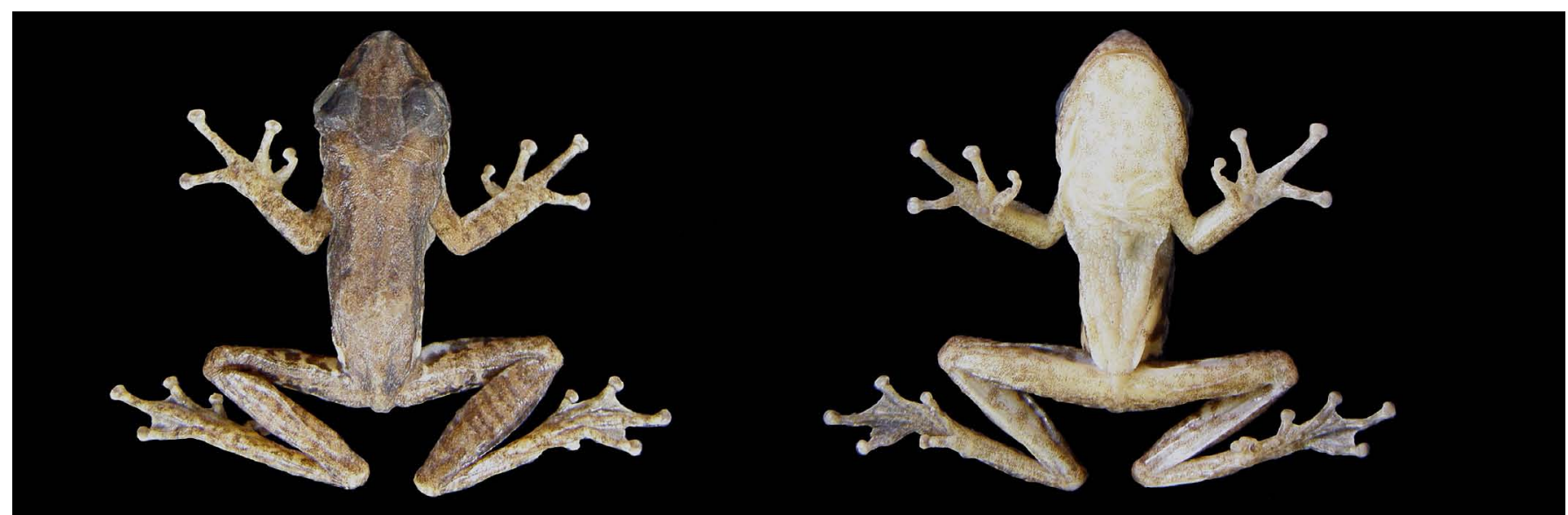

FigURE 1. Dorsal (A) and ventral (B) view of an adult male Scinax centralis (MZUFV 6509, 22.05 mm snout-vent length) from Campo Alegre de Goiás, state of Goiás, Brazil. 


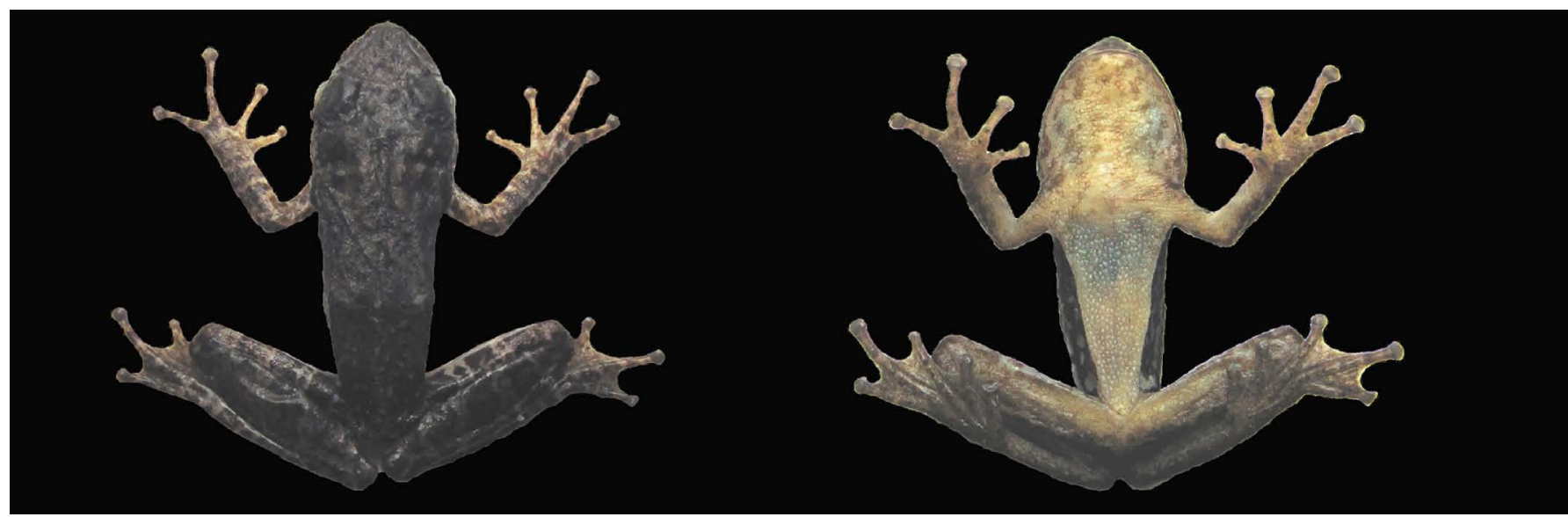

FiguRE 2. Dorsal (A) and ventral (B) view of an adult female Scinax centralis (MZUFV 6511, 26.55 mm snout-vent length) from Campo Alegre de Goiás, state of Goiás, Brazil.

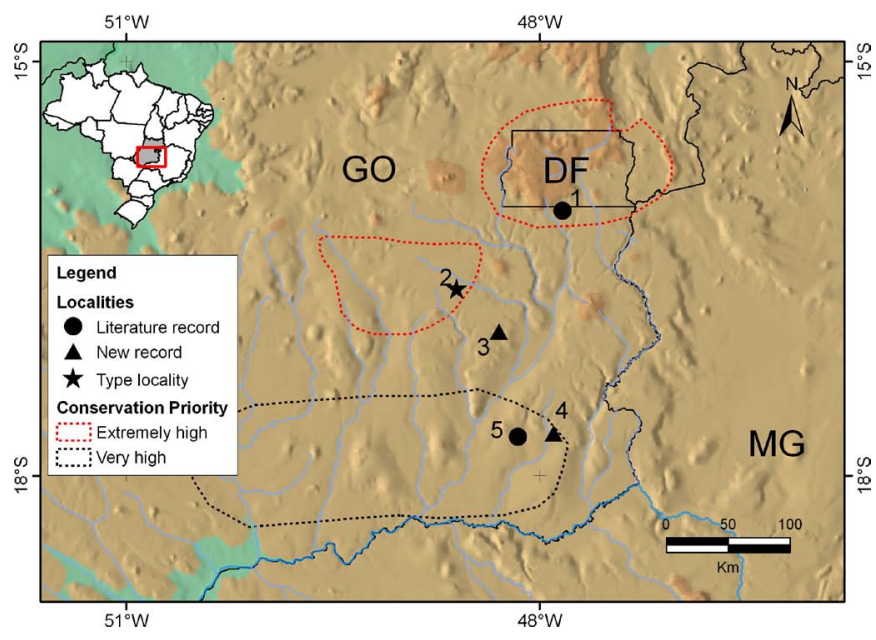

FIGURE 3. Geographic distribution of Scinax centralis in Brazil. DF, Distrito Federal; GO, state of Goiás; MG, state of Minas Gerais. 1, Brasília (Mesquita stream); 2, Silvânia (Floresta Nacional de Silvânia); 3, Orizona (Córrego do Fogo); 4, Campo Alegre de Goiás (Mariquita stream); 5, Ipameri.

The records of Scinax centralis from Campo Alegre de Goiás and Orizona represent, respectively, a range extension of $c a .30 \mathrm{Km}$ east and $c a .60 \mathrm{Km}$ southeast from Ipameri. (Figure 3). All known populations of $S$. centralis remain restricted to the Paranaíba River Basin. It is important to note that four of the five localities from where $S$. centralis was reported are located in priority areas for conservation of biodiversity in Cerrado and Pantanal (MMA, 2007), including the new record from the municipality of Campo Alegre de Goiás, located in the priority area of Alto Paraná region (Figure 3).

The Scinax catharinae species group is more diversified in the Atlantic Forest. Species that inhabit the Cerrado domain (e.g. S. centralis, S. canastrensis and S. machadoi) (Bastos 2007) occupy habitats (gallery forests) similar to the Atlantic Forest species (Faivovich et al. 2002). Bastos et al. (2003) and Pombal and Bastos (1996) related that the reproduction sites of this species are streams in riparian forest or ponds with constant change of water in open area at the border of riparian forest. Additionally, Alcantara et al. (2007) reported a patch of rivulet with insignificant water flow (considered by these authors as a permanent lentic water body) as reproduction sites. The observation
TABLE 1. Descriptive statistics of morphometric characters of Scinax centralis specimens collected at municipalities of Campo Alegre de Goiás and Orizona, state of Goiás. m: mean, Min: minimum, Max: maximum, SD: standard deviation. SVL (snout-vent length), HL (head length), HW (head width), END (eye-nostril distance), TD (tympanum diameter), ED (eye diameter), IOD (intraorbital distance), THL (thigh length), TBL (tibia length) and FL (foot length).

\begin{tabular}{lllllllll}
\hline Sex & \multicolumn{3}{l}{ Males (n=4) } & \multicolumn{5}{c}{ Females (n=3) } \\
\hline & m & Min & Max & SD & m & Min & Max & SD \\
\hline SVL & 23.25 & 21.41 & 25.33 & 1.83 & 26.01 & 24.9 & 26.58 & 0.96 \\
HL & 8.37 & 6.86 & 9.16 & 1.06 & 9.18 & 8.96 & 9.4 & 0.21 \\
HW & 8.10 & 7.38 & 9.06 & 0.81 & 8.99 & 8.86 & 9.2 & 0.17 \\
END & 4.22 & 3.73 & 4.80 & 0.44 & 4.70 & 4.53 & 4.86 & 0.16 \\
TD & 1.49 & 1.28 & 1.75 & 0.20 & 1.70 & 1.43 & 1.95 & 0.25 \\
ED & 3.24 & 2.73 & 3.78 & 0.54 & 3.75 & 3.68 & 3.85 & 0.09 \\
IOD & 2.45 & 2.16 & 2.56 & 0.19 & 3.03 & 2.65 & 3.35 & 0.35 \\
THL & 11.13 & 9.46 & 12.78 & 1.80 & 13.27 & 13.23 & 13.33 & 0.05 \\
TBL & 12.84 & 11.70 & 14.18 & 1.23 & 14.40 & 14.00 & 14.75 & 0.37 \\
FL & 17.29 & 15.86 & 18.90 & 1.62 & 19.64 & 19.08 & 20.33 & 0.63 \\
\hline
\end{tabular}

of individuals of $S$. centralis in activity in a small temporary pond resulting from decreased flow of Córrego do Fogo is consistent with what was reported by Alcantara et al. (2007), suggesting that $S$. centralis may use other sites without constant change of water for reproduction.

ACKNOWLEDGMENTS: We thank the anonymous referee for valuable comments on the manuscript. Carla Santana Cassini and José Lelis Pontes for help during fieldwork. Rogério Pereira Bastos for identification of the specimens.

\section{Literature Cited}

Alcantara, M.B., L.P. Lima and R.P. Bastos. 2007. Breeding activity of Scinax centralis (Anura, Hylidae) in Central Brazil. Iheringia, Série Zoologia 97(4): 406-410.

Bastos, R.P. 2007. Anfíbios do Cerrado; p. 87-100 In: L.B. Nascimento and M.E. Oliveira (eds). Herpetologia no Brasil II. Belo Horizonte: Sociedade Brasileira de Herpetologia.

Bastos, R.P., J.A.O. Motta, L.P. Lima and L.D. Guimarães. 2003. Anfíbios da Floresta Nacional de Silvânia, estado de Goiás. Goiânia: R. P. Bastos. $82 \mathrm{p}$.

Brandão, R.A. and A.F.B. Araujo. 2002. A Herpetofauna Associada a Matas de Galeria no Distrito Federal; p. 560-604 In: J.F. Ribeiro, C.E.L. Fonseca and J.C. Sousa-Silva (org.). Cerrado: Caracterização e Recuperação de Matas de Galeria. 1 ed. Planaltina: EMBRAPA/CPAC. Faivovich, J. 2002. A cladistic analysis of Scinax (Anura: Hylidae). 
Cladistics 18: 367-393

Faivovich, J., C.F.B. Haddad, P.C.O. Garcia, D.R. Frost, J.A. Campbell and W.C. Wheeler. 2005. Systematic review of the frog family Hylidae, with special reference to Hylinae: Phylogenetic analysis and taxonomic revision. Bulletin of the American Museum of Natural History 294: $1-240$.

MMA - Ministério do Meio Ambiente. 2007. Biodiversidade do Cerrado e Pantanal: áreas e ações prioritárias para conservação. Série Biodiversidade 17. Brasília: MMA. $540 \mathrm{p}$.
Pombal, J.P. and R.P. Bastos. 1996. Nova espécie de Scinax Wagler, 1830 do Brasil central (Amphibia, Anura, Hylidae). Boletim do Museu Nacional, Nova Série, Zoologia 371: 1-11.

RECEIVED: September 2009

REviSED: October 2009

ACCEPTED: January 2010

PUBLISHED ONLINE: March 2010

EDITORIAL RESPONSIBILITY: Marcelo N. de C. Kokubum 